\title{
IMPLEMENTASI PERMAINAN DALAM PEMBELAJARAN MATEMATIKA DI SEKOLAH DASAR
}

\section{IMPLEMENTATION OF GAMES IN MATHEMATICS LEARNING IN ELEMENTARY SCHOOL}

\author{
Nia Wahyu Wijayanti \\ Sekolah Dasar Negeri Tegalombo 2 Surakarta \\ Email:juniya90@gmail.com
}

\begin{abstract}
Article Info
Abstract
Learning media draws students' attention to teaching activities while stimulating students' study

\begin{tabular}{l}
\multicolumn{1}{c}{ Article Info } \\
\hline \\
Historical Articles \\
Submitted: 2021-06-03 \\
Revised: 2021-06-16 \\
Issued: 2021-06-30 \\
\hline
\end{tabular}

Keywords: Implementation, Game Media, Elementary School activities one of them is a game media. The purpose of this study is to learn the implementation of the media game in the higher quality of mathematical learning in elementary schools. This study use a defined class action study procedure and 3 cycle. Data collection techniques were observation, documentation, rubric, tests and notes of the game. The games applied were the snakes and ladders, circuit, and the monopoly of modified with math material in elementary school. Games media in the three sub studies was not intended to apply concepts, but as an outgoing practice. The media game builds enthusiasm for students to improve their skills with pleasure to encouraged student's skills. Based on the result presented media can help improve the quality of mathematics at elementary school views and teacher skills, student activities, increased learning outcomes, math material quality and the study situation. It is proven from the results of the scores that have increased in each cycle (I, II and III) through the implementation of the three media. Game media can help in improving the quality of mathematics learning in elementary schools, especially high grades.
\end{abstract}

Kata kunci:

Permainan,

Pembelajaran

Matematika, Permainan

Ular Tangga,

Permainan Sirkuit,

Monopoli Bintang

\section{Abstrak}

Media pembelajaran menjadi menarik perhatian siswa pada kegiatan belajar mengajar jika merangsang kegiatan belajar siswa. Salah satu media tersebut adalah media permainan. Penelitian ini bertujuan adalah untuk mengetahui implementasi media permainan dalam peningkatan kualitas pembelajaran matematika di sekolah dasar. Penelitian ini menggunakan prosedur penelitian tindakan kelas yang terdiri dari 3 siklus. Teknik pengumpulan data adalah observasi, dokumentasi, rubrik, tes dan catatan lapangan. Permainan yang diterapkan adalah permainan ular tangga, permainan sirkuit, dan monopoli bintang yang dimodifikasi dengan materi matematika sekolah dasar. Media permainan dalam ketiga sub penelitian tersebut bukan dimaksudkan untuk menerapkan konsep, melainkan sebagai pelatih ketrampilan. Media permainan membangkitkan semangat bagi siswa untuk meningkatkan keterampilannya dengan perasaan senang. Perasaan senang inilah yang mendorong siswa untuk terus berlatih. Hasil penelitian ini menunjukkan bahwa media permainan dapat membantu dalam meningkatkan kualitas pembelajaran matematika di sekolah dasar ditinjau dari aspek keterampilan guru, aktivitas siswa, peningkatan hasil belajar, kualitas materi dan iklim belajar. Dibuktikan dari hasil skor yang mengalami peningkatan pada setiap siklus (I, II dan III) melalui implementasi ketiga media. Media permainan dapat membantu dalam peningkatan kualitas pembelajaran matematika di sekolah dasar khusunya kelas tinggi. 


\section{PENDAHULUAN}

Pendidikan tidak semata-mata berusaha untuk mencapai hasil belajar, tetapi bagaimana memperoleh hasil atau proses belajar yang terjadi pada diri anak (Kartikasari, 2010). Matematika sangat erat kaitannya dengan kehidupan sehari-hari, namun juga merupakan salah satu pelajaran yang sering menimbulkan kecemasan pada siswa sekolah dasar (Huang et al., 2014).

Usia perkembangan kognitif siswa SD masih terikat dengan objek konkret yang dapat ditangkap oleh panca indra. Dalam berkomunikasi antar pebelajar dan pembelajar terkadang sering menimbulkan salah penafsiran bahkan salah dimengerti oleh si pembelajar (Atapukang, 2016). Pemahaman siswa merupakan faktor yang penting dalam pelaksanaan pembelajaran (Meylinda et al., 2016). Untuk itu pembelajaran matematika yang abstrak, siswa memerlukan alat bantu berupa media, dan alat peraga yang dapat memperjelas apa yang akan disampaikan oleh guru. Media adalah komponen sumber belajar atau wahana fisik yang mengandung materi instruksional di lingkungan siswa, yang dapat merangsang siswa untuk belajar. Berdasarkan definisi tersebut peneliti menyimpulkan bahwa media pembelajaran memiliki manfaat yang besar dalam memudahkan siswa mempelajari materi pelajaran.

Media pembelajaran yang digunakan harus dapat menarik perhatian siswa pada kegiatan belajar mengajar dan lebih merangsang kegiatan belajar siswa. Salah satu media pembelajaran yang dapat mengaktifkan siswa adalah media permainan yang mengarah pada pendidikan dengan tujuan meningkatkan kemampuan matematika. Permainan dalam pembelajaran matematika di sekolah bukan untuk menerangkan melainkan suatu cara atau teknik untuk mempelajari atau membina keterampilan dari suatu materi tertentu (Sukayati \& Wulandari, 2009), sedangkan untuk mendukung peningkatan kemampuan berhitung adalah melalui permainan ular tangga.

Keterampilan guru, aktivitas siswa dan hasil belajar matematika dapat meningkatkan daya serap dan pemahaman siswa melalui permainan edukatif terhadap pelajaran matematika serta meningkatkan minat siswa dalam belajar (Syahsiah, 2008). Beberapa pakar pendidikan mengatakan bahwa tujuan utama digunakan permainan dalam matematika adalah untuk memberikan motivasi kepada siswa agar siswa menjadi senang (Magnatis, 2019). Penelitian ini bertujuan untuk mengetahui hasil implementasi media permainan dalam pembelajaran matematika dan untuk mengetahui peranan media dalam peningkatan kualitas pembelajaran matematika di Sekolah Dasar khususnya di kelas tinggi.

\section{METODE}

Penelitian ini merupakan penelitian guru tentang implementasi permainan pada pembelajaran matematika di Sekolah Dasar. Penelitian ini bersifat deskriptif sehingga penelitian ini merupakan penelitian kualitatif (Arrosyad et al., 2020). Penelitian ini mengungkap tentang penerapan media permainan dalam proses belajar mengajar. Penelitian ini dilakukan di SDN Tegalombo 2 dan dua sekolah lain di sekitarnya yaitu SDN Jetiskarangpung 2 serta SDN Kaloran 1. Ketiga sub penelitian tersebut menggunakan prosedur penelitian tindakan kelas yang terdiri dari 3 siklus, setiap siklus 2 pertemuan dengan tahapan perencanaan, pelaksanaan, observasi dan refleksi. Teknik pengumpulan data adalah observasi, dokumentasi, rubrik, tes dan catatan lapangan. Variabel dalam penelitian ini adalah: (1) Keterampilan guru, (2) Aktivitas siswa, (3) Iklim pembelajaran, (4) Materi pembelajaran, (5) Media pembelajaran, (6) Hasil belajar.

\section{HASIL PENELITIAN}

Peneliti memperoleh data hasil penelitian dari hasil 3 sub penelitian. Dari ketiga sub penelitian, semuanya mengimplementasikan permainan pada pembelajaran matematika di 
sekolah dasar, namun dengan permainan yang berbeda. Permainan pada sub penelitian yang pertama adalah permainan ular tangga. Permainan ini diimplementasikan bersama dengan model Problem Based Learning variasi snowball throwing. Permainan pada sub penelitian yang kedua adalah permainan sirkuit. Permainan ini diimplementasikan dengan model Problem Based Learning variasi Snowball Throwing. Permainan pada sub penelitian yang ketiga adalah permainan monopoli bintang. Permainan ini diimplementasikan dengan model Number Head Together variasi Snowball Throwing.

Ketiga sub penelitian tersebut dilaksanakan di SD Negeri di Kabupaten Sragen terutama di kelas tinggi (kelas IV dan V) yang terfokus pada implementasi permainanpada pembelajaran matematika di sekolah dasar. Hal ini menyebabkan sintaks pembelajaran matematika dari ketiga penelitian ini juga ada perbedaan. Sintaks Pelaksanaan Pembelajaran dalam sub penelitian yang pertama (pembelajaran Matematika dengan PBL variasi Snowball Throwing berbantuan ular tangga) adalah: (1) Guru menyampaikan materi pokok yang akan disampaikan, (2) Guru membentuk kelompok dan menjelaskan prosedur pelaksanaan snowball throwing, Guru memanggil ketua kelompok untuk pembagian tugas berupa masalah, Siswa menuliskan istilah/konsep yang belum diketahui dalam soal pada selembar kertas, (5) Setiap kelompok menggulung dan melemparkan bola kertas ke kelompok lain, (6) Siswa mengklarifikasi istilah/konsep yang diperoleh, (7) Siswa merumuskan masalah, (8) Siswa dalam menganalisis masalah, (9) Guru melakukan pengawasan terhadap kegiatan siswa dalam menata gagasan, (10) Guru membimbing siswa memformulasikan tujuan pembelajaran, (11) Guru melakukan pengawasan kepada siswa dalam mencari informasi tambahan, (12) Siswa menggabungkan informasi dan membuat laporan, (13) Siswa mempresentasikan laporan hasil diskusinya, (14) Siswa memainkan ular tangga, (15) Guru memberikan lembar evaluasi, (16) Guru memberikan penghargaan kepada pemenang permainan ular tangga. Standar Kompetensi yang digunakan dalam penelitian ini adalah menggunakan pecahan dalam pemecahan masalah.

\section{PEMBAHASAN}

Hasil sub penelitian ini menunjukkan peningkatan: (1) keterampilan guru pada siklus I dengan rata-rata skor 22,5 (baik), siklus II rata- rata skor 33,5 (sangat baik), siklus III rata- rata skor 36,5 (sangat baik); (2) aktivitas siswa pada siklus I rata-rata skor 13,9 (cukup), siklus II ratarata skor 20,6 (baik), siklus III rata-rata skor 25,25 (baik); (3) ketuntasan klasikal hasil belajar siswa memperoleh 47,8\%, pada siklus II yaitu 69,5\%, siklus III mendapat 85,7\%; kualitas materi siklus I rata-rata skor2,5 (cukup), siklus II mendapat rata- rata skor 5 (baik), siklus III rata-rata skor 6 (sangat baik); kualitas media siklus I rata-rata skor3 (cukup), siklus II mendapat rata-rata skor 6,5 (sangat baik), siklus III mendapat rata-rata skor 7 (baik); kualitas iklim belajar pada siklus I mendapat rata- rata skor 3 (cukup), siklus II rata-rata skor 5 (baik), siklus III rata-rata skor 6,5 (sangat baik).

Sintaks Pelaksanaan Pembelajaran dalam sub penelitian yang kedua (pembelajaran matematika dengan PBL variasi Snowball Throwing berbantuan permainan sirkuit) adalah (1) Orientasi siswa pada masalah dengan menyajikan pertanyaan berupa permasalahan dalam kehidupan sehari hari, (2) Guru menyampaikan materi, (3) Siswa dibagi menjadi beberapa kelompok dengan setiap kelompok 5-6 anggota, (4) Siswa dibimbing guru dalam menyelesaikan LKK, (5) Siswa menyajikan hasil karya dari penyelesaian LKK, (6) Siswa melakukan permainan sirkuit untuk menguji seberapa banyak materi yang dikuasai dengan alokasi waktu \pm 15-20 menit, (7) Guru memantau jalanya permainan sirkuit dari setiap kelompoknya, (8) Siswa menerima penghargaan berupa sertifikat sesuai hasil dari permainan sirkuit, (9) Siswa bersama guru mengevaluasi hasil dari permainan Sirkuit melalui metode Snowball Throwing. Setiap kelompok membuat 1 pertanyaan disembar kertas yang dibentuk seperti gumpalan bola, pertanyaan tersebut mengenai kesulitan dalam menjawab soal-soal yang ada di permainan 
sirkuit, kemudian bola dilempar dari kelompok satu ke kelompok lainnya, sehingga setiap kelompok mendapatkan bola untuk diberi kesempatan menjawab pertanyaan yang tertulis dalam kertas tersebut, (10) Siswa bersama guru menyimpulkan materi yang telah dipelajari. Standar kompetensi yang digunakan dalam penelitian ini adalah memahami sifat-sifat bangun dan hubungan antarbangun

Hasil sub penelitian ini menunjukkan peningkatan: (1) keterampilan guru siklus I skornya 25 (baik), siklus II 31 (baik), siklus III 36,5 (sangat baik); (2) aktivitas siswa siklus I skornya 23,15 (cukup), siklus II 28,65 (baik), siklus III 34,1 (baik); (3) iklim pembelajaraan siklus I skornya 4 (baik), siklus II 5 (baik), siklus III 6,5 (sangat baik); (4) materi pembelajaraan siklus I skornya 7 (baik), siklus II 8,5 (baik), siklus III 10,5 (sangat baik); (5) media pembelajaran siklus I skornya 12,5 (baik), siklus II 16 (sangat baik), siklus III 18 (sangat baik); (6) hasil belajar siklus I pada ranah kognitif memperoleh nilai rata-rata 64,3 siklus II 69,7 dan siklus III 73,2. Ketuntasan klasikal pada ranah kognitif siklus I sebesar 63\%, siklus II 78\%, siklus III 88\%. Hasil belajar ranah psikomotorik ketuntasan belajar pada siklus I sebesar $68 \%$, siklus II $88 \%$ dan siklus III 100\%. Hasil belajar ranah afektif siklus I skornya 25 (baik), siklus II 31 (baik), siklus III 36,5 (sangat baik).

Sintaks Pelaksanaan Pembelajaran dalam sub penelitian yang ketiga (pembelajaran matematika dengan NHT variasi Snowball Throwing berbantuan permainan monopoli bintang) adalah (1) Guru membentuk kelompok secara heterogen, (2) Guru membagikan Lembar Kegiatan Kelompok (LKK) kepada masing-masing kelompok, (3) Kelompok mendiskusikan jawaban dari LKK yang diberikan oleh guru dan setiap siswa harus mempunyai jawabannya, (4) Guru memanggil salah satu nomor siswa untuk mempresentasikan hasil diskusi kelompok, (5) Siswa yang ditunjuk nomor kepala wajib menjawab soal yang diberikan, apabila tidak bisa guru menunjuk nomor yang lain dengan cara menyebutkan nomor kepala yang dipakai siswa atau nomor kendali, (6) Guru membacakan aturan permainan monopoli bintang, (7) Siswa memainkan permainan monopoli bintang, (8) Guru membimbing dalam permainan monopoli bintang, (9) Siswa mendapatkan reward sesuai dengan jumlah soal yang dijawab, (10) Guru memberikan intruksi untuk membuat soal yang harus di jawab oleh masing-masing siswa yang terdapat dalam kelompok tersebut, (11) Guru melempar kertas soal yang telah dibuat oleh masing-masing siswa. Jika mendapatkanya wajib untuk menjawabnya, (12) Siswa mengerjakan soal yang telah didapat, (13) Guru menutup pembelajarandengan memberikan kesimpulan dan evaluasi. Standar kompetensi yang digunakan dalam penelitian ini adalah menggunakan pecahan dalam pemecahan masalah.

Hasil sub penelitian ini menunjukkan peningkatan: (1) Keterampilan guru pada setiap siklus berturut-turut memperoleh rata-rata skor 51,5 (baik); 53,5 (sangat baik) dan 56 (sangat baik). (2) Aktivitas siswa pada setiap siklus berturut-turut memperoleh rata-rata skor 13,94 (cukup); 20,11 (baik)dan 27,44 (baik). (3) Kualitas iklim pembelajaran pada setiap siklus berturut- turut memperoleh rata-rata skor 5,5 (baik), 5,5 (baik) dan 7,5 (sangat baik). (4) Kualitas materi pembelajaran pada setiap siklus berturut-turut memperoleh rata-rata skor 5 (baik); 5 (baik) dan 6,5 (sangat baik). (5) Kualitas media pembelajaran pada setiap siklus berturut-turut memperoleh rata-rata skor 5,5 (baik); 6,5 (sangat baik) dan 6,5 (sangat baik). (6) Hasil belajar siswa pada setiap siklus berturut-turut memperoleh nilai rata-rata 54 (ketuntasan klasikal 16\%); 70 (ketuntasan klasikal 67\%) dan 77 (ketuntasan klasikal 89\%).

Kata "Media" berasal dari bahasa latin yang merupakan bentuk jamak dari "medium", secara harfiah berarti perantara atau pengantar (Nurseto, 2012). Media terdiri atas perangkat lunak dan perangkat keras. Perangkat lunak (software) berisi pesan atau informasi pendidikan yang biasanya disajikan dengan mempergunakan peralatan.

Media yang sering digunakan adalah media cetak (diktat, modul, handout, buku teks, majalah, surat kabar, dan sebagainya), dan didukung dengan alat bantu sederhana yang masih 
tetap digunakan seperti papan tulis/white board dan kapur/spidol (Kariman \& Mulia, 2012). Fungsi media dalam proses belajar mengajaryaitu untuk meningkatkan rangsangan peserta didik dalam kegiatan belajar (Ali, 2009). Penggunaan media pembelajaran sangat membantu dalam proses belajar mengajar baik bagi guru maupun para siswa (Rohmawati \& Sukanti, 2012). Depdiknas (2004) menyebutkan bahwa media yang berkualitas dapat dilihat dari: (1) dapat menciptakan pengalaman belajar yang bermakna, (2) memfasilitasi proses interaksi antara guru dan siswa, (3) dapat memperkaya pengalaman belajar siswa, (4) dapat mengubah suasana belajar yang aktif menjadi pasif. Bermain adalah suatu kegiatan yang dilakukan dengan atau tanpa mempergunakan alat yang menghasilkan pengertian atau memberikan informasi, memberi kesenangan, atau mengembangkan imajinasi anak (Yusuf et al., 2011). Berbagai inovasi media yang dikembangkan untuk membantu proses pembelajaran baik yang berupa visual seperti komjinasi (komik imajinasi) atau sejenisnya (Dinanti et al., 2020). Dengan permainan, siswa dapat merumuskan pemahaman tentang suatu konsep, kaidah-kaidah, unsur-unsur pokok, proses, hasil, dampak, dan seterusnya. Dunia anak tidak dapat dipisahkan dari proses bermain. Bermain merupakan kegiatan yang menyenangkan dan berangkat dari keinginan anak untuk memperoleh kesenangan. Jika dipadukan dengan belajar maka akan memberikan rasa nyaman (rileks) dan tidak tegang sehingga dalam belajar anak merasa senang seperti sedang bermain. (Yusuf et al., 2011) mengemukakan bahwa belajar sambil bermain memiliki beberapa manfaat, diantaranya: (1) Mengajak orang terlibat penuh (2) Meningkatkan proses belajar (3) Membangun kreativitas diri (4) Mencapai tujuan dengan ketidaksadaran.

Meraih makna belajar melalui pengalaman (6) Memfokuskan siswa sebagai subyek belajar. menyatakan ada dua jenis permainan dalam pembelajaran yaitu permainan pertama mengarah pada pendidikan dengan tujuan tertentu (Yusuf et al., 2011). Permainan kedua adalah jenis permainan yang digunakan dalam proses belajar dan semata-mata sebagai permainan murni (ice breaker), bukan untuk membahas suatu topik tertentu tapi hanya untuk menghidupkan suasana. Menurut Ahmadi dalam (Pitadjeng, 2006), permainan adalah suatu perbuatan yang mengandung keasyikan dan dilakukan atas kehendak sendiri, bebas tanpa paksaan, dengan tujuan untuk mendapatkan kesenangan pada waktu melakukan kegiatan tersebut. Dengan melihat ketiga sintak pembelajaran pada sub penelitian, ketiga media permainan tersebut diberikan setelah kegiatan presentasi diskusi kelompok guna memantapkan materi yang telah dipelajari Media permainan dalam ketiga penelitian tersebut bukan dimaksudkan untuk menerapkan konsep, melainkan sebagai pelatih ketrampilan. Media permainan membangkitkan semangat bagi siswa untuk meningkatkan ketrampilannya dengan perasaan senang. Perasaan senang inilah yang mendorong siswa untuk terus berlatih. Semua permainan ini dilakukan secara berkelompok sehingga siswa juga termotivasi untuk saling bersaing satu sama lain. Tingkat kompetisi menjadi lebih tinggi.

Hasil dari sub penelitian pertama ini adalah melalui model PBL variasi snowball throwing berbantuan media ular tangga dapat meningkatkan kualitas pembelajaran matematika di kelas IV SDN Tegalombo 2. Hasil dari sub penelitian kedua ini adalah dapat meningkatkan kualitas pembelajaran matematika kelas $\mathrm{V}$ yang meliputi keterampilan guru, aktivitas siswa, kualitas iklim pembelajaran, kualitas materi pembelajaran, kualitas media pembelajaran dan hasil belajar. Hasil dari sub penelitian ketiga ini adalah melalui NHT variasi Snowball Throwing berbantuan permainan monopoli bintang dapat meningkatkan kualitas pembelajaran matematika kelas IV yang meliputi keterampilan guru, aktivitas siswa, kualitas iklim pembelajaran, kualitas materi pembelajaran, kualitas media pembelajaran dan hasil belajar Dari ketiga sub penelitian yang dilakukan diperoleh hasil yang sama. Hasil ketiga sub penelitian tersebut adalah media permainan dapat membantu dalam peningkatan kualitas pembelajaran matematika. Penggunaan media pembelajaran dengan sistem permainan diharapkan dapat menimbulkan kegiatan belajar mengajar yang menarik dan langsung melibatkan siswa dalam kegiatan belajar mengajar secara 
aktif sehingga dapat membuat pembelajaran berjalan tidak membosankan, melatih kerjasama, meningkatkan pemahaman siswa terhadap materi yang diajarkan, menumbuhkan minat belajar siswa, mempercepat proses informasi serta menyelesaikan masalah, sekaligus dapat meningkatkan kepekaan social (Siskawati et al., 2016).

\section{SIMPULAN}

Berdasarkan hasil penelitian dari implementasi permainan ular tangga, sirkuit dan monopoli pada pembelajaran matematika di sekolah dasar disimpulkan bahwa, ketiga permainan tersebut dapat meningkatkan kualitas pembelajaran matematika di sekolah dasar, khususnya bagi kelas tinggi. Peningkatan kualitas pembelajaran ditinjau dari aspek keterampilan guru, aktivitas siswa, peningkatan hasil belajar, kualitas materi dan iklim belajar. Dibuktikan dari hasil skor yang mengalami peningkatan pada setiap siklus (I, II dan III) melalui implementasi ketiga media.

\section{REFERENSI}

Ali, M. (2009). Pengembangan Media Pembelajaran Interaktif Mata Kuliah Medan Elektromagnetik. Jurnal Edukasi@Elektro, 5(1), 11-18.

Arrosyad, M. I., Oktaviani, S. N., Eftia, H., Karisma, N., \& Meliyana, B. (2020). Nilai-nilai Budaya Sekolah dalam Pembinaan Aktivitas Keagamaan Siswa. Atthulab: Islamic Religion Teaching and Learning Journal, 5(1), 129-139. https://doi.org/10.15575/ath.v5i1.7697

Atapukang, N. (2016). Kreatif membelajarkan pembelajar dengan menggunakan media pembelajaran yang tepat sebagai solusi dalam berkomunikasi. Ejournal Undiksha, 17(2), 4552.

Depdiknas. (2004). Kerangka dasar kurikulum. Depdiknas.

sDinanti, R. P., Ardiansah, F., \& Romadon. (2020). Pengembangan media komjinasi (komik imajinasi) pada pembelajaran bahasa indonesia untuk siswa kelas $\mathrm{V}$ sekolah dasar. Cendekiawan, 2(2), 64-68. https://cendekiawan.unmuhbabel.ac.id/index.php/CENDEKIAWAN

Huang, Y. M., Huang, S. H., \& Wu, T. T. (2014). Embedding diagnostic mechanisms in a digital game for learning mathematics. Educational Technology Research and Development, 62(2), 187207. https://doi.org/10.1007/s11423-013-9315-4

Kariman, T. M., \& Mulia, E. (2012). Pemanfaatan Weblog sebagai media pembelajaran untuk meningkatkan hasil belajar bahasa inggris. Jurnal Teknologi Pendidikan, 5(1).

Kartikasari, G. (2010). Pengaruh media pembelajaran berbasis multimedia terhadap motivasi dan manusia studi eksperimen pada siswa Kelas V MI Miftahul Huda Pandantoyo. Pengaruh Media Pembelajaran Berbasis Multimedia, 16(1), 1-77. http://ejournal.iaintulungagung.ac.id/index.php/dinamika/article/download/139/114

Magnatis, U. (2019). Upaya meningkatkan prestasi belajar siswa kelas IV SD Negeri 7 Sungailiat mata pelajaran matematika tentang operasi hitung campuran melalui metode demonstrasi. Cendekiawan, 1(1), 20-28. https://doi.org/10.35438/cendekiawan.v1i1.155

Meylinda, F., Yuwana, S., \& Sukartiningsih, W. (2016). Pengembangan media pembelajaran keterampilan berbicara dengan program adobe flash untuk siswa kelas V SD. Jurnal Review 
Pendidikan Dasar: Jurnal Kajian Pendidikan Dan Hasil Penelitian, 2(3).

Nurseto, T. (2012). Membuat media pembelajaran yang menarik. Jurnal Ekonomi Dan Pendidikan, 8(1), 19-35. https://doi.org/10.21831/jep.v8i1.706

Pitadjeng. (2006). Pembelajaran matematika yang menyenangkan. Depdiknas RI.

Rohmawati, E. D., \& Sukanti, S. (2012). Pengaruh cara belajar dan penggunaan media pembelajaran terhadap prestasi belajar akuntansi siswa Kelas XI IPS SMA Negeri 2 Bantul tahun ajaran 2011/2012. Jurnal Pendidikan Akuntansi Indonesia, 10(2), 153-171. https://doi.org/10.21831/jpai.v10i2.918

Siskawati, M., Pargito, \& Pujiati. (2016). Pengembangan media pembelajaran monopoli untuk meningkatkan minat belajar geografi siswa. Jurnal Studi Sosial, 4(1), 72-80.

Sukayati, \& Wulandari, S. (2009). Pembelajaran tematik di SD. Departemen Pendidikan Nasional, 53(9), 1689-1699.

Syahsiah. (2008). Pengarub penggunaan permainan monopoli sebagai media pengajaran matematika terhadap minat belajar matematika siswa Sekolah Dasar (Studi eksperimen di SDIT Al-Hikmah Pela Mampang Kelas $V$ pada pokok basaban bangun datar). UIN Syarif Hidayatullah Jakarta.

Yusuf, Y., Auliya, U., \& SR, Z. (2011). Sirkuit pintar: melejitkan kemampuan matematika dan bahasa inggris dengan metode ular tangga. Visimedia Pustaka. 